\title{
Genuinely addressing gender and sexuality in the language classroom is essential
}

Edition 2, 2020

Dr Claire Maree

DOI: 10.37839/MAR2652-550X2.12

Li Kotomi's award-winning novel Hitori Mai (Solo Dance) illustrates both the joys and anxieties of learning a language.

$\mathrm{Li}$, a Taiwanese-born author writing in Japanese, crafts a non-linear retelling of the protagonist Cho's experiences of depression and coming-out as a lesbian-identified woman. The Japanese language, and language education, play pivotal roles in this complex story, which gives insights into experiences of those who identify and/or are classified as sexual minorities in a time of increased awareness of sexual orientation and gender identity (SOGI) issues on a global scale.

The protagonist, Cho, has a desire to read the literature of popular Japanese author Murakami Haruki in the original, and not in translation. This motivates her to learn Japanese, and to enroll in Japanese language classes at university. Eventually, Cho moves to Tokyo from Taiwan and begins to work in the metropolis.

A journal entry of the protagonist illustrates some of the terrain that Cho negotiates in the language classroom:

\section{$1^{\text {st }}$ October (Weds) rain}

In "Japanese Conversation 2" we practiced using counters. After saying "as all of you are really smart, you must have lots of children and pass on your superior genes," our teacher called on us one by one asking "how many children do you want," "how 
many children will you have" and making us answer. When I was asked "Ms Cho, how many children will you have," I really didn't know what to answer. I feel silent. (Author's translation)[1]

A few entries later, on the $7^{\text {th }}$ November, Cho laments not being able to find a partner to practice conversation in class. She also writes of returning to the classroom to fetch something she left behind, only to discover her classmates talking about her behind her back. Then, in the next entry dated $20^{\text {th }}$ November Cho recounts "coming out" to her therapist.

\section{Language education and the vulnerability of the language learner}

Cho's experiences of learning and working in an additional language as told by $\mathrm{Li}$ in Solo Dance resonate with many students enrolled in language subjects in tertiary institutions in Australia.

Many students are motivated by a desire to enjoy popular culture-film, television dramas, manga and anime-in the original language. Many want to further develop their language skills in order to (re)connect with the cultures and peoples they have met on their sojourns. Others wish to deepen their relationships with family and culture by further strengthening their understanding of their heritage language. A long-term goal for many of our students is to live and/or work in the language(s) they study.

We can frame these motivations as wants, wishes-as desires. Within the framework of queer pedagogy, such desires are, "a force that compels us to acquire knowledge and engage with others".

Language learning is fundamentally tied to identity. We express ourselves, our thoughts, our desires, and the mundane details of our daily lives in and through 
language (among other meaning-making channels such clothing, musical tastes and so on). The making of one's self in another language is a process full of discoveries. It is a joyous one in many ways. Yet, the process is also pocketed with anxietyproducing moments.

Why? Because, in our language classrooms, alongside developing our understanding of new ways to put words together, we formulate ourselves in and through the target language. This practice pivots on the notions we have about ourselves that we bring to the classroom. And, as we acquire knowledge of our selves through engaging with others, it also plays out in our classroom interactions with our peers. In language classrooms we are labelled according to the classificatory practices salient to that language community.

Solo Dance prompts us to reflect on the vulnerability of the language learner. It urges us to direct our attention to how sexual orientation, gender identification, mental health and acceptance are understood and navigated in mainstream language classrooms.

Indeed, critical approaches to language education mandate a re-engagement with sexuality orientation and gender identity. This is particularly relevant in the Australian and Japanese contexts.

\section{Respect in Australian tertiary language classrooms}

Re-engagement with sexuality orientation and gender identity (SOGI) in our tertiary language classrooms is particularly relevant in the context of the results of the Respect.Now.Always (RNA) project.

The report prepared by the Australian Human Rights Commission (AHRC) states that: 
- across Australian universities, women were almost twice as likely to report being sexually harassed in university settings than men, and more than three times more likely to report being sexually assaulted;

- $44 \%$ of students who identified as bisexual and 38\% who identified as gay, lesbian or homosexual reported being sexually harassed in a university setting, compared with $23 \%$ of students who identified as heterosexual;

- trans and gender diverse students (45\%) were more likely to have been sexually harassed in a university setting in 2016 than women (25\%) and men (15\%). (A breakdown of the classifications used and more detailed analysis can be found in the AHRC's Change the Course.

In response to the RNA report, Universities Australia released Guidelines for universities responding to reports of sexual assault and sexual harassment and Principles for respectful supervisory relationships, and universities across the sector have put a variety of initiatives in place.

The 10-point plan released as an initial response by Universities Australia in 2017 makes mention of a multitude of language-related issues. These issues include the language of consent, access to interpreters, inclusive language; and the respectful use of language in the classroom and in work with research and research training. The University of Melbourne's Respect at the university website also stresses "respect," emphasing that respect is everyone's right and everyone's responsibility. Diversity and inclusion are highlighted as being valued by the institution. The University's LGBTI+ policies are clearly shown on the central website, and increasingly more training and mentoring programs are organised and delivered by the Pride in Action Network.

Given the higher percentage of both student and teaching cohorts who self-identify as lesbian, gay, bisexual, transgender, queer, intersex and/or non-binary in some Faculties, such as Arts, the RNA figures are especially troubling. A working group led by the University of Melbourne's Associate Dean of Equal Opportunity and Diversity came together in 2019 to develop resources for teaching and learning staff 
within the Faculty. Following collaboration between the working group and the Arts Teaching Innovation team, and with support from the Pride in Action Network, the Teaching with Respect for Gender and Sexuality resource was launched within the Faculty in October 2019.

The rationale for the initiative is outlined in the project summary report which underlines the value of queer pedagogical approaches. Citing poet and scholar Stacey Waite's Teaching queer: radical possibilities for writing and knowing, the report notes that "queer pedagogical approaches remind us of the nexus between 'the lived world and theoretical practice' and usefully inform the 'vibrant' and 'adaptive' intellectual environment we seek to create in the Faculty of Arts." Queer pedagogy refers to approaches that attempt to problemetise heteronormativity as the only valorized understanding of gender and sexuality, and to question everyday assumptions and stereotypes about sexual orientations and gender identities.

\section{Additional needs for respectful multilingual and multicultural teaching}

Specific multilingual and multicultural resources are also needed. Firstly, to create greater respect for diversity among monolingual students and/or colleagues on tertiary campuses who may not be aware of the ways in which gender and/or sexuality manifest in other languages. Secondly, to provide resources in the diversity of languages that are taught on campuses that can be shared and used in the classroom by specialist and non-specialist colleagues alike. Renowned feminist scholar and writer Sara Ahmed cautions in her work on race and diversity in institutions that diversity is symbolic and material. It circulates "both as a word and in a document." It is necessary to do more than merely brandish these words in the belief that they will magically conjure up "diversity" and "inclusion."

The Teaching with Respect for Gender and Sexuality resource contains, amongst other things, information about the University's commitment to enabling a safe, 
inclusive and respectful community; statistics on the health and wellbeing of students, including LGBTIQA+ students; quick guides to sex, gender and sexualityrelated ideas, including preferred names and personal pronouns; information about gender-related etiquette, particularly in relation to culture and language; 'best practice' strategies for facilitating inclusive classroom interactions and learning; and online multilingual resources that can be used in the classroom.

The limitations of token inclusivity are clear. In language education, it is not sufficient to include a token bisexual, lesbian, gay and/ transgender character as a peripheral character in a language textbook. To do so runs the risk of not affecting change. As pedagogy scholar and psychoanalyst Deborah P. Britzman writes, an absence of any thought towards gender identity and sexual orientation in our teaching leads us to question what it is that "makes something unthinkable?". We must pause to consider the limits of our knowledge and the mundane processes that make gender and sexuality relevant to a minoritized few but unquestioned for the majority.

\section{Sexual orientation and gender identity (SOGI) in the Japanese language classroom}

Increasingly, the necessity to both question the dominance of Eurocentric queer approaches to language education and to bring SOGI issues to the fore in a diversity of language classrooms is being highlighted. It is also relevant to Japanese language education in the run up to the Tokyo Olympic \& Paralympic Games (postponed now to 2021 due to the COVID-19 pandemic) when Japan has seen the emergence of an "LGBT boom".

The contemporary "LGBT boom" is in part propelled by the discourse of diversity and inclusion in the International Olympic Charter. Diversity awareness and training has made significant inroads into Japanese corporate culture. The commodification of "LGBT" as a term, however, removes it from existing local political struggles for 
legal rights and social recognition by and for LGBTQIA+ peoples which have a welldocumented and diverse history in Japan.

In 2018 the term "LGBT" was included for the first time in new $7^{\text {th }}$ edition of Iwanami's famous Kojien Japanese language dictionary: a major Japanese dictionary. As the definition conflated sexuality and gender identification, a campaign to have it amended quickly gathered speed. The resultant official amendment was announced less than two weeks later.

The $7^{\text {th }}$ edition of Kojien is the first revision of this significant dictionary in a decade. It contains a number of major changes. In the entry for ai (love), for example, the expression "opposite sex" is now bracketed. This simple amendment effectively opens the word to the possibility of love that transcends heteronormative configurations and/or gender binary norms. We must pause to acknowledge that changes such as these have linguistic, cultural and political impact.

Campaigns to amend dictionary definitions have a history in Japanese SOGI activism. One of the most well cited cases is the campaign to change the definitions of "homosexuality" in dictionaries, encyclopedia and other reference texts.

This emerged as part of a case against Tokyo Municipal Government (TMG) lodged by lesbian and gay group OCCUR. In 1990, OCCUR members held an overnight camp at a municipal youth centre. After introducing themselves at the mandatory evening hostel meeting, members were harassed by other groups. OCCUR lodged a formal legal complaint. Access to the youth center facilities by all "homosexual groups" was subsequently withdrawn due sex-segregation rules for accommodation based on moral grounds of protecting youth from sexual activity.

Ignorance surrounding LGBTQIA+ issues was unavoidable, it was claimed by many, given that dictionary and encyclopedias defined "homosexuality (dōseiai)" as a deviance. To counteract this, OCCUR engaged in a successful campaign to lobby dictionary editorial boards. Reference to "deviance" was removed from the Kojien 
entry for "homosexuality (dōseiai)" in 1991. The TGM lost in the Tokyo District Court and appealed to the Tokyo High Court, who in 1997 ruled in favour of compensation to OCCUR.

It wasn't until two decades later, however, that one of the major encyclopedias, Heibonsha's Sekai Daihyakkajiten (World Encyclopedia) altered the entry that OCCUR had questioned. As activist and writer Nagayasu Shibun notes in a 2017 Yomiuri newspaper article, a series of editorial board and publisher changes led to the revisions being delayed.

\section{Token inclusivity is not good enough}

It is no longer tenable to argue that SOGI is not relevant to language education. Not least in the context of the Respect.Now.Always project, nor in the context of the "LGBT boom" in Japan.

Research in Japanese gender, language and sexuality has long debunked many of the stereotypes that exist around gendered language use, and critically engaged with sexuality. The shift in language ideologies-the beliefs we have about language use, and how we justify those beliefs-that are often cited as evidence for maintaining gendered language education are also well-documented.

Fewer and fewer speakers use what might have traditionally been referred to as Japanese women's language and/or Japanese men's language in their everyday speech. And, although most Japanese language textbooks no longer prescribe these as ideal forms for students to learn and produce, there is still a persistent ideology that gender binaries cannot be negotiated within classrooms, and that the classroom is no place for alternative sexual identities to be expressed.

Japanese popular culture is full of references to how individual speakers negotiate the gendered aspects of the Japanese language, and queer language is, as I have argued in my work, an essential component of contemporary Japanese culture. We 


\section{MELBOURNE ASIA REVIEW}

need look no further that the 100 LGBTQ Coming out video to engage with the diversity of gender identities and sexual orientations expressed by self-identifying individuals in Japanese. Released to coincide with National Coming Out Day annually since 2017, these short videos feature messages from people across Japan. When engaging with these issues, it is important to be mindful, however, this is not an argument for tokenistic "inclusivity", but an opportunity to also question the dominant ideologies of Japanese language that permeate its teaching.

Footnote [1] - The original reads: 口日本語会話二』で助数詞の使い方の練習をした。 先生は「皆さんは頭が良いので、子供を沢山産んで優秀な遺伝子を残しなさい」と言っ た後、一人ずつ当てて「ロさんは子供が何人欲しいですか」や「子供を何人産みますか」 と訊いて答えさせた。「趙さんは子供を何人産みますか」と訊かれた時はなんと答えれ ばいいか分からず。黙り込んでしまった。」

Image: Tokyo Rainbow Pride 2017. Credit: The Asahi Shimbun/Getty Images. 